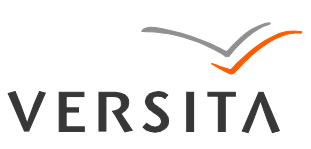

GEOCHRONOMETRIA 39(3) 2012: 221-226

DOI 10.2478/s13386-012-0012-6

Available online at

www.springerlink.com

\title{
QUARTZ OSL DATING OF SAND DUNES IN GHAGGAR BASIN, NORTHWESTERN INDIA
}

\author{
YORINAO SHITAOKA ${ }^{1}$, HIDEAKI MAEMOKU ${ }^{2}$ and TSUNETO NAGATOMO ${ }^{3}$ \\ ${ }^{1}$ Institute for Geothermal Sciences, Kyoto University, 3088-176 Noguchibaru, Beppu 894-0903, Japan \\ ${ }^{2}$ Graduate School of Education, Hiroshima University, 1-1-1 Kagamiyama, Higashi-hiroshima 739-8524, Japan \\ ${ }^{3}$ Nara University of Education, Takabatake-cho, Nara 630-8528, Japan
}

Received 28 July $2011 \quad$ Accepted 23 April 2012

\begin{abstract}
Several studies have used luminescence dating to investigate sand mobilization activity in extreme western areas and the southern margin of the Thar Desert, India. However, room exists for a chronology of sand profiles for the northern margins of the Thar Desert. The Ghaggar River flood plain at Rajasthan, northwestern India, in the northern margin of the Thar Desert, is bordered by sand dunes. Elucidation of the environmental changes of the Ghaggar Basin requires knowledge of many aspects of sand dune formation.

We measured optically stimulated luminescence (OSL) using the single aliquot regenerative-dose (SAR) protocol for sand of eight palaeo-dunes and two flood silts of both sides of the present Ghaggar Basin and Chautang Basin flood plains. Their OSL ages were obtained respectively, as 15-10 ka or $5 \mathrm{ka}$, and 9-8 ka. Results of this study reinforce the hypothesis that sand dune deposition had started or had already been completed by 15-10 ka. Aeolian deposition was subdued by enhanced moisture during 9-8 ka. Our interpretation is that, at least since $5 \mathrm{ka}$, the scale of the flood plain of the Ghaggar River has remained equivalent to that of the present day.
\end{abstract}

Keywords: north margins of the Thar Desert, Ghaggar River, dune sand, environmental change, OSL dating.

\section{INTRODUCTION}

Embraced by long arms of sand dunes, the Ghaggar River flood plain in the northern margins of the Thar Desert is located at Rajasthan, northwestern India (Fig. 1). These dune arms, which comprise linear and parabolic dunes, extend from the southern Thar Desert. The dunes are from several to several tens of meters high and ca. $500 \mathrm{~m}$ long on average. Aeolian activity in the sand dunes is restricted to periods when south-west monsoon winds prevail (Kar, 1993). Although aeolian activity occurs in

Corresponding author: Y. Shitaoka

e-mail: shitaoka@bep.vgs.kyoto-u.ac.jp regions with a precipitation regime of $<250 \mathrm{~mm} / \mathrm{a}$ in the Thar Desert, the dunes in Ghaggar Basin have been stable in areas with 200-250 $\mathrm{nm}$ annual rainfall (Juyal et al., 2003; Singhvi and Kar, 2004).

Using thermoluminescence (TL), Chawla et al. (1992) investigated dunes in the western extremity of the Thar Desert, western Rajasthan, considering the residual TL level. Their data suggest a peak in sand mobilization activity at ca. $14 \mathrm{ka}$. Since then, sand mobilization decreased because of the proliferation of moisture during 13-6 ka. Singhvi et al. (1982) measured the ages of stabilized sand dunes in the southern margin of the Thar Desert, Rajasthan, using TL, considering the residual TL level. The ages of the greatest depth of sand dunes were 


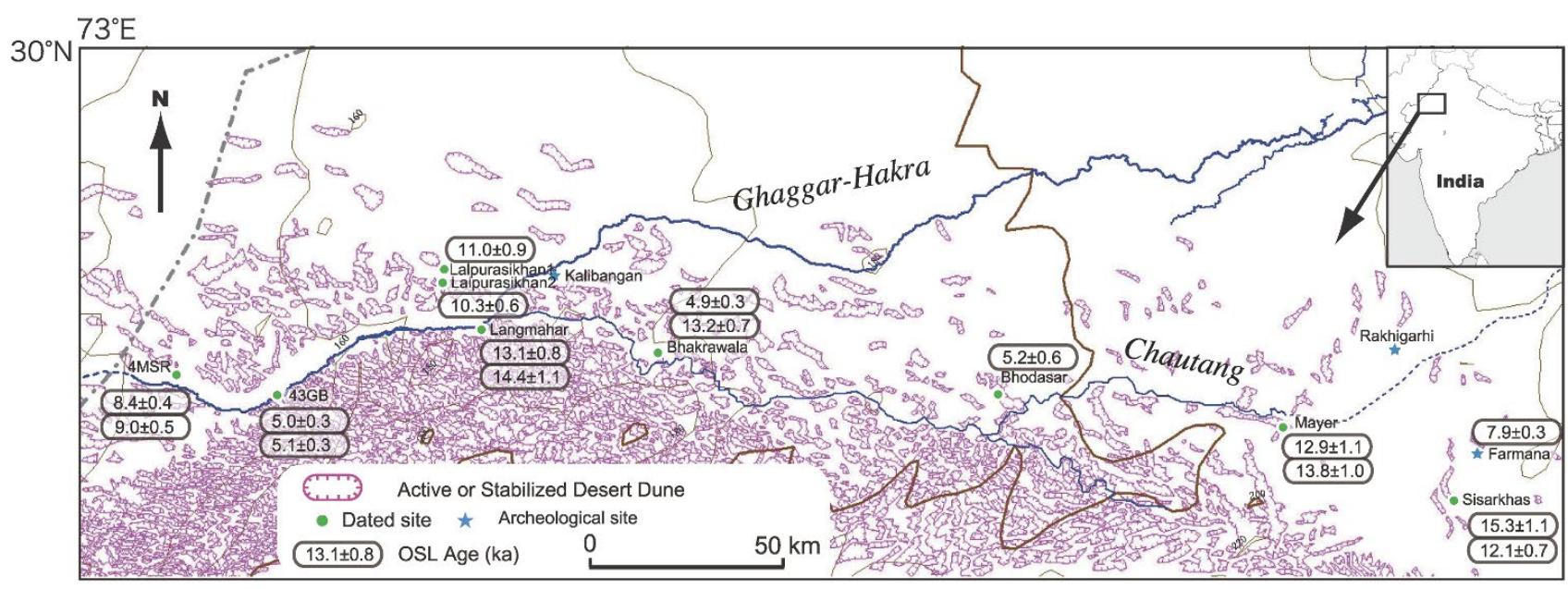

Fig. 1. Location map of this study and relation between OSL ages of eight palaeo-sand dunes and flood plain of the Ghaggar River.

indicated as 16,190 a and 20,280 a. Juyal et al. (2003) used blue-green light-stimulated luminescence with the multiple aliquot protocol to measure aeolian deposits in the southern margin of the Thar Desert, eastern Gujarat. Their main conclusions were that the dune deposition commenced at around $26 \mathrm{ka}$, corresponding to Oxygen Isotope Stage-3, and that it continued episodically until ca. 5 ka. During 12-8 ka, aeolian deposition was subdued because of enhanced moisture. Saini and Mujtaba (2010), used optically stimulated luminescence (OSL) dating based on the single aliquot regenerative-dose (SAR) protocol (Murray and Wintle, 2000). They found that the palaeochannel identified between Fatehabad and Hosanga, in the northwestern part of Haryana, received sufficient water supplies between $5.9 \mathrm{ka}$ and $4.3 \mathrm{ka}$. However, the chronology of sand profiles in the northern margins of the Thar Desert remains as an unsettled question. The present study, using OSL dating with SAR protocol, reveals the age of sand dunes and flood silts existing on both sides of the present flood plain of Ghaggar Basin, located in the north margins of the Thar Desert. Ascertaining the age of the sand dune formation is important for understanding environmental changes that have taken place in the Ghaggar Basin.

\section{SITE AND SAMPLING}

Samples for OSL dating were collected from eight palaeo-dunes (Sisarkhas, Maiyer, Bhodasar, Rangmahal, Bhakrawala, Lal Pura Sikhan, 43GB) and two flood silts (Farmana, 4MSR) limited to both sides of the present flood plain of the Ghaggar Basin and its branch, the Chautang Basin (Fig. 1). Two palaeo-dunes near Lal Pura Sikhan were sampled. These samples were dune sand (Fig. 2a). The dune samples were collected near the base of each sand dune as much as possible. Two flood silt layers were sampled from archaeological sites of Farmana and near 4MSR village. Two samples were silty
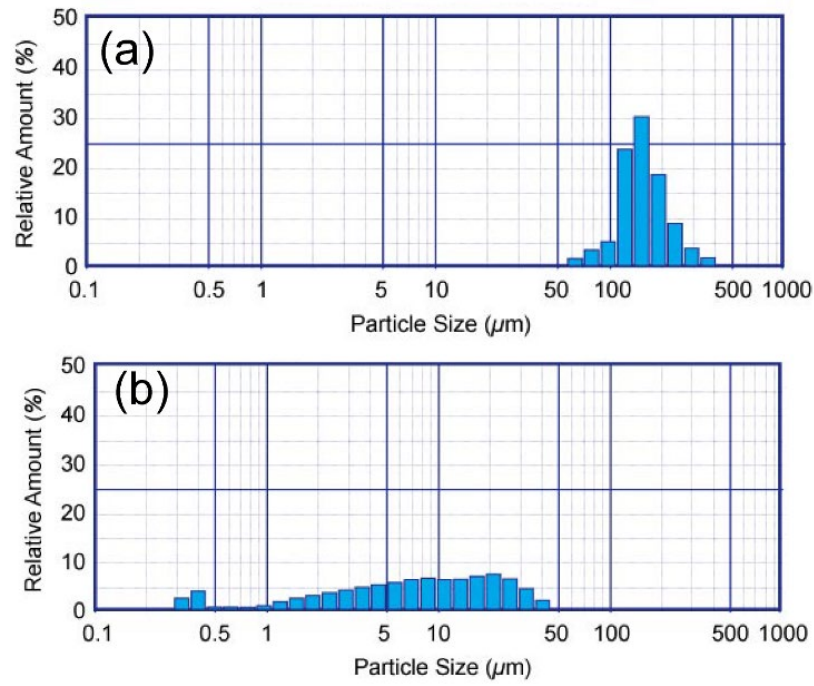

Fig. 2. Typical results of grain-size distributions at dated sites: a) Bhakrawala; b) $4 M S R$.

sand (Fig. 2b). The Research Institute for Humanity and Nature, Japan excavated the Farmana site during years 2006-2008 (Shinde et al., 2011). This site dates from pre/early to mature Harappan. The archaeological site near 4MSR, located on the right bank of the Ghaggar River, dates from the early-to-mature Harappan era. Samples for use in OSL dating were collected from flood silt under archaeological sediment. Moreover, a sample for radiocarbon $\left({ }^{14} \mathrm{C}\right)$ dating, a shell, was collected from archaeological sediment of the archaeological site near 4MSR for comparison with the OSL age of flood silt.

Sampling sites were covered with an opaque cloth. All samples were collected after the top surface layer, which was ca. $5 \mathrm{~cm}$ thick, had been removed. The upper sample is No. 1 and the lower sample is No. 2 at each site. The interval between the upper and lower sample position was about $1 \mathrm{~m}$ (Fig. 3). Additional samples were 

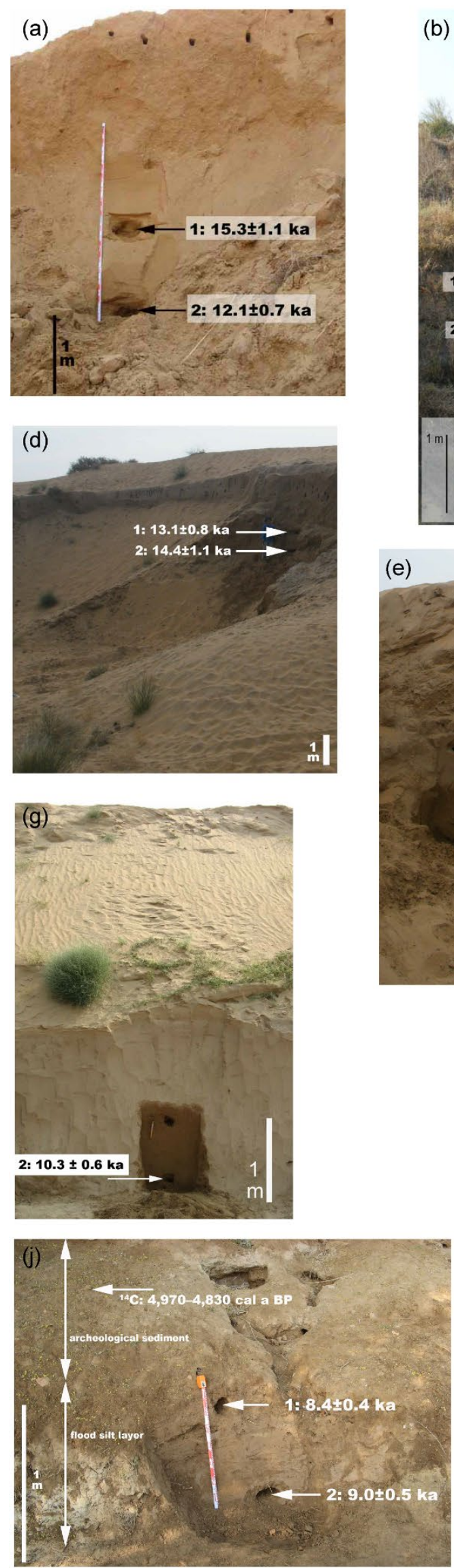

(b)
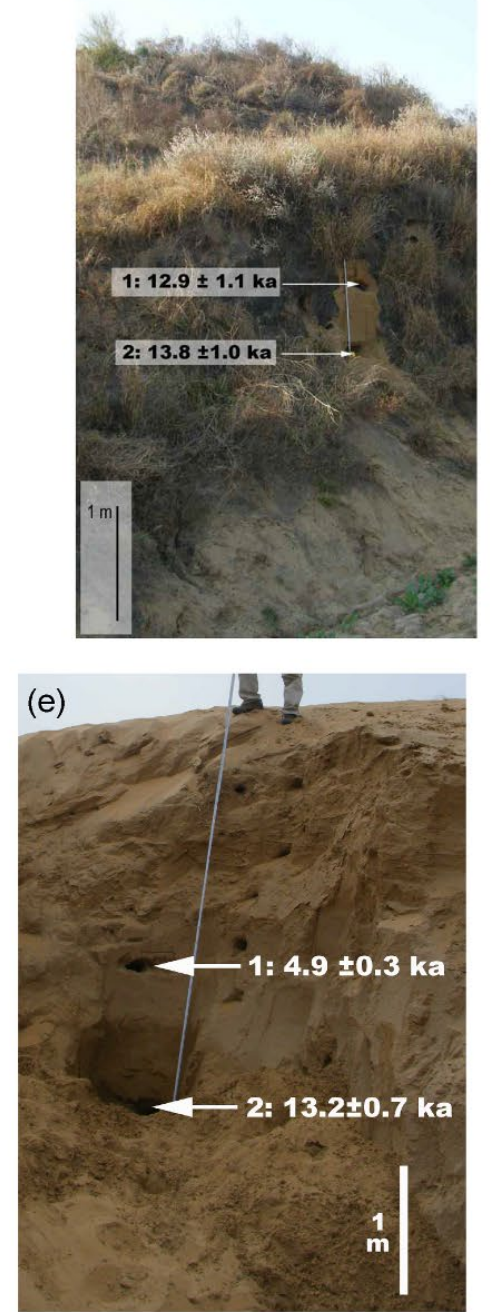

(h)

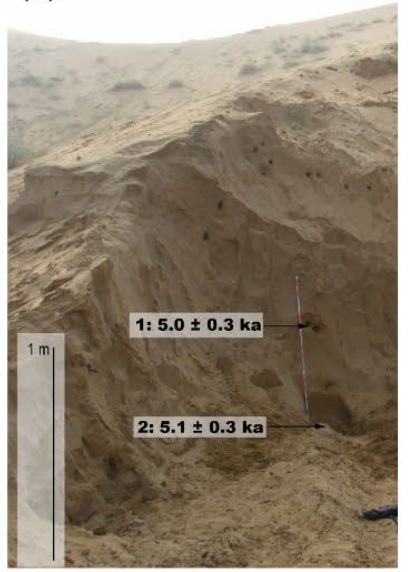

Fig. 3. Representative sections of palaeo-sand dunes $(a-h)$ and flood silts $(i-j)$ at sampling locations: a) Sisarkhas; b) Maiyer; c) Bhodasar; d) Rangmahal; e) Bhakrawala; f) Lal Pura Sikhan-1; g) Lal Pura Sikhan-2; h) 43GB; i) Farmana; i) $4 M S R$.
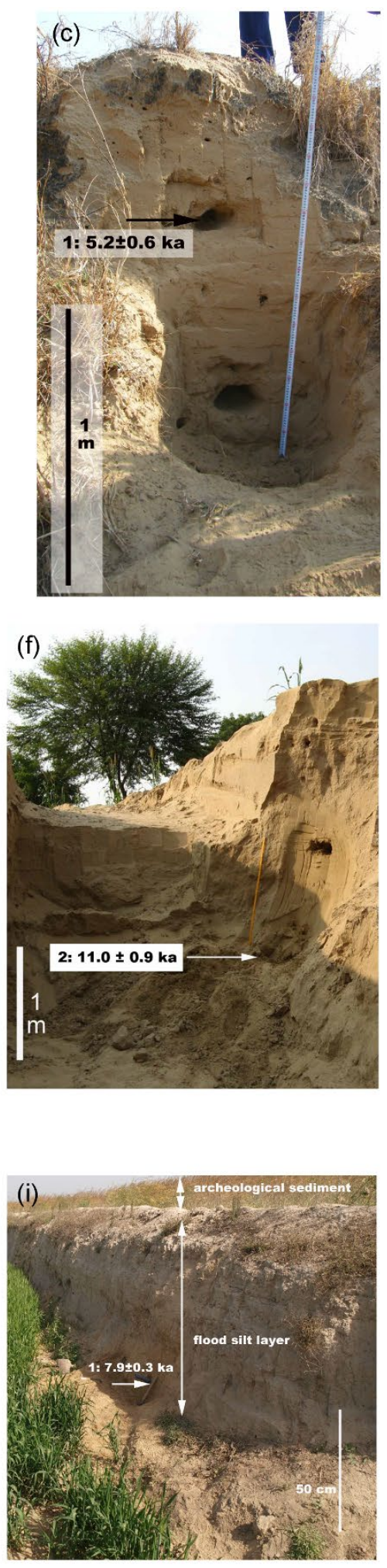
collected from the sand dune immediately surrounding the OSL sample for estimation of the dose rate (annual dose) of the sand dune.

\section{OSL DATING}

\section{Sample preparation and instrumentation}

Minerals in each collected sample were separated roughly into fine and coarse grains $(\mathrm{CG})$ in water. Dried CG samples were sieved into a fraction of 250-50 $\mu \mathrm{m}$ using standard sieves. The sieved samples were treated with $10 \% \mathrm{H}_{2} \mathrm{O}_{2}$ for $16 \mathrm{hr}$ and $20 \% \mathrm{HCl}$ for $90 \mathrm{~min}$. Initially non-magnetic minerals were separated from magnetic minerals using a Franz magnetic separator. Feldspar, quartz and all non-magnetic minerals were treated together with $20 \% \mathrm{HF}$ for $90 \mathrm{~min}$ and $46 \% \mathrm{HF}$ for $10 \mathrm{~min}$ to separate the quartz from the others and to etch the outer part of the grains. The etched quartz fraction was sieved into $150-75 \mu \mathrm{m}$. The purity of quartz extracts was verified using infrared stimulation. If feldspar had remained, HF treatment was repeated.

OSL was measured using an OSL/TL reader (NRL99-OSTL; Neoark Corp.) (Nagatomo et al., 2007; 2009) equipped with an array of 32 blue LEDs $(470 \mathrm{~nm})$ at Nara University of Education (NUE), Japan. The OSL from a sample was detected using a PMT tube (R1140P; Hamamatsu Photonics KK, Japan) housed in a cooling unit ($\left.20^{\circ} \mathrm{C}\right)$ through two condensing lenses and a filter $(2 \mathrm{~mm}$ thick Hoya U-340; Kenko Tokina Corp.). Irradiation was conducted using a Risø ${ }^{90} \mathrm{Sr}{ }^{90} \mathrm{Y}$ beta-ray source built into the OSL reader at NUE.

\section{Palaeodose and annual dose estimation}

Respective palaeodoses were measured using the SAR protocol shown in Table 1 . After each regenerativedose OSL signal $\left(L_{\mathrm{i}}\right)$ was measured, a small test dose (3 Gy) was applied. Then its OSL signal was measured $\left(T_{\mathrm{i}}\right)$ to monitor for sensitivity changes. Each sensitivitycorrected OSL for doses was calculated by dividing $L_{\mathrm{i}}$ by the respective $T_{\mathrm{i}}$ (i.e. $L_{\mathrm{i}} / T_{\mathrm{i}}$ ). The SAR protocol consists of a series of regenerative and test-dose measurements to create a sensitivity-corrected growth curve onto which the sensitivity-corrected natural OSL signal $\left(L_{\text {natural }} / T_{\text {natural }}\right)$ is interpolated to obtain a palaeodose value. To select

Table 1. Protocol for SAR measurement.

\begin{tabular}{clc}
\hline Step & Treatment & Observed \\
\hline $1^{\text {(a) }}$ & Give dose, $\mathrm{Di}$ & - \\
2 & Preheat $\left(230^{\circ} \mathrm{C}\right.$ for $\left.60 \mathrm{~s}\right)$ & - \\
3 & Stimulate for $100 \mathrm{~s}$ at $120^{\circ} \mathrm{C}$ & $\mathrm{Li}$ \\
4 & Give test dose, $3 \mathrm{~Gy}$ & - \\
5 & Cut heat $\left(160^{\circ} \mathrm{C}\right)$ & - \\
6 & Stimulate for $100 \mathrm{~s}$ at $120^{\circ} \mathrm{C}$ & $\mathrm{Ti}$ \\
7 & Return to 1 & - \\
\hline
\end{tabular}

(a) Step 1: For the natural sample, $\mathrm{i}=0$ and $\mathrm{D}_{0}=0 \mathrm{~Gy}$. appropriate preheat conditions using the SAR protocol, a preheat temperature plateau and dose recovery test were conducted. Preheat temperatures at $200-280^{\circ} \mathrm{C}$ at intervals of $20^{\circ} \mathrm{C}$ for $60 \mathrm{~s}$ were tested. The cut-heat was $160^{\circ} \mathrm{C}$. A plateau of preheating was found at $200-240^{\circ} \mathrm{C}$ (Fig. 4). Therefore, we selected a preheat temperature $230^{\circ} \mathrm{C}$ for routine determination. A thermal transfer test (Wintle and Murray, 2006) was performed for each sample. Recuperation was $<10 \%$ for all samples. The dose recovery test $(n=3)$ was within $\pm 10 \%$ of the administered dose. The result suggests that the SAR procedure can recover a laboratory dose.

Annual doses (dose rate) were measured using a gamma-ray spectrometer. The concentrations of $\mathrm{U}, \mathrm{Th}$, and $\mathrm{K}$ in the samples were analyzed using a Ge gammaray detector (EGSP 8785; Eurisys Mesures) at NUE. The annual dose was calculated using the dose-rate conversion factors of Adamiec and Aitken (1998). Contributions of the cosmic-dose rate to the annual dose were assumed according to methods proposed in previous studies by Prescott and Hutton (1994), Nagatomo et al. (2009), and Shitaoka et al. (2009).

\section{RESULTS AND DISCUSSION}

The OSL decay curve and growth curve for $43 \mathrm{~GB}$ (No. 2) are shown in Fig. 5. The growth curve can be well fitted to the exponential form. The OSL ages are presented in Table 2: the ages of sand dunes bordering both sides of the Ghaggar River were $15-10 \mathrm{ka}$ or $5 \mathrm{ka}$ (Fig. 3). The OSL ages of sand dunes in this study are fairly consistent with the results reported by Singhvi et al. (1982), Chawla et al. (1992), Juyal et al. (2003), and Saini and Mujtaba (2010). Results show that dunebuilding activity in the Thar Desert had already started at ca. 26-10 ka and that it continued until ca. $5 \mathrm{ka}$.

The OSL ages of flood silts were 9-8 ka. Plural samples of carbonized wood collected from the artefact horizon of the Farmana archaeological site were subjected to

${ }^{14} \mathrm{C}$ dating (Palaeo-labo AMS dating group, 2011). The

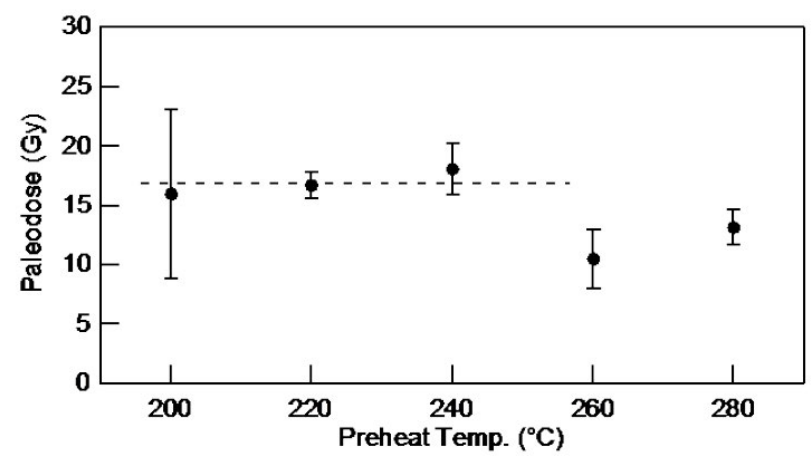

Fig. 4. Preheat temperature plateau measurement of $43 G B$ (No. 2). Averages of three aliquots are shown at respective temperatures. A preheating plateau is apparent at $200-240^{\circ} \mathrm{C}$. 
Table 2. Results of OSL dating.

\begin{tabular}{|c|c|c|c|c|c|c|c|c|}
\hline Sampling location & Sample No. & $\begin{array}{c}\text { Palaeodose } \\
\text { (Gy) }\end{array}$ & Aliquots & $\begin{array}{c}\mathrm{U} \\
\text { (ppm) }\end{array}$ & $\begin{array}{c}\mathrm{Th} \\
\text { (ppm) }\end{array}$ & $\begin{array}{c}\mathrm{K} \\
\text { (wt \%) } \\
\end{array}$ & $\begin{array}{c}\text { Annual dose } \\
\text { (mGy/a) }\end{array}$ & $\begin{array}{c}\text { OSL age } \\
\text { (ka) }\end{array}$ \\
\hline \multirow{2}{*}{ Sisarkhas } & 1 & $38.3 \pm 2.5$ & 11 & 1.78 & 10.68 & 1.22 & $2.50 \pm 0.08$ & $15.3 \pm 1.1$ \\
\hline & 2 & $32.0 \pm 1.6$ & 18 & 1.75 & 11.59 & 1.28 & $2.66 \pm 0.09$ & $12.1 \pm 0.7$ \\
\hline \multirow{2}{*}{ Maiyer } & 1 & $30.2 \pm 2.2$ & 11 & 1.64 & 10.95 & 1.00 & $2.34 \pm 0.10$ & $12.9 \pm 1.1$ \\
\hline & 2 & $34.1 \pm 2.0$ & 9 & 1.80 & 12.06 & 1.03 & $2.47 \pm 0.09$ & $13.8 \pm 1.0$ \\
\hline Bhodasar & 1 & $13.4 \pm 1.0$ & 3 & 1.79 & 10.80 & 1.19 & $2.57 \pm 0.25$ & $5.2 \pm 0.6$ \\
\hline \multirow{2}{*}{ Rangmahal } & 1 & $26.4 \pm 1.3$ & 11 & 1.05 & 7.97 & 1.08 & $2.01 \pm 0.08$ & $13.1 \pm 0.8$ \\
\hline & 2 & $34.1 \pm 2.3$ & 9 & 1.49 & 9.97 & 1.21 & $2.37 \pm 0.08$ & $14.4 \pm 1.1$ \\
\hline \multirow{2}{*}{ Bhakrawala } & 1 & $11.2 \pm 0.4$ & 23 & 1.50 & 11.28 & 0.98 & $2.27 \pm 0.09$ & $4.9 \pm 0.3$ \\
\hline & 2 & $28.2 \pm 1.1$ & 27 & 1.59 & 9.77 & 0.99 & $2.14 \pm 0.07$ & $13.2 \pm 0.7$ \\
\hline Lal Pura Sikhan-1 & 2 & $33.4 \pm 2.3$ & 13 & 2.62 & 12.82 & 1.37 & $3.03 \pm 0.11$ & $11.0 \pm 0.9$ \\
\hline Lal Pura Sikhan-2 & 2 & $32.4 \pm 1.7$ & 12 & 2.77 & 13.97 & 1.51 & $3.15 \pm 0.09$ & $10.3 \pm 0.6$ \\
\hline \multirow{2}{*}{$43 G B$} & 1 & $11.7 \pm 0.7$ & 20 & 1.51 & 8.98 & 1.21 & $2.33 \pm 0.08$ & $5.0 \pm 0.3$ \\
\hline & 2 & $11.5 \pm 0.6$ & 30 & 1.42 & 9.44 & 1.15 & $2.23 \pm 0.08$ & $5.1 \pm 0.3$ \\
\hline Farmana & 1 & $46.9 \pm 1.5$ & 18 & 5.70 & 28.15 & 2.31 & $5.95 \pm 0.16$ & $7.9 \pm 0.3$ \\
\hline \multirow{2}{*}{$4 M S R$} & 1 & $23.9 \pm 1.0$ & 22 & 2.46 & 12.43 & 1.58 & $2.83 \pm 0.08$ & $8.4 \pm 0.4$ \\
\hline & 2 & $25.4 \pm 1.1$ & 26 & 2.67 & 13.12 & 1.55 & $2.81 \pm 0.08$ & $9.0 \pm 0.5$ \\
\hline
\end{tabular}

Samples of Farmana and 4MSR are flood silt. Others are palaeo-dune sand.
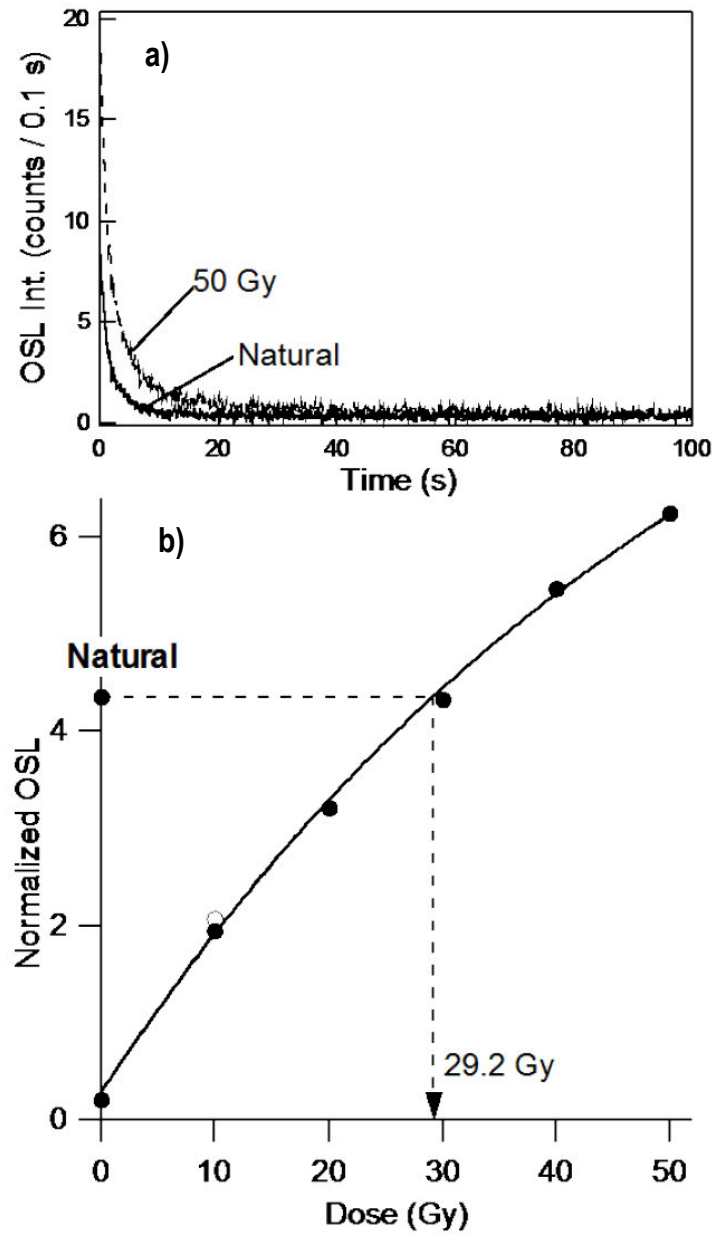

Fig. 5. a) OSL decay curve of natural and 50 Gy for Maiyer (No. 1). b) Growth curve of an aliquot of Maiyer (No. 1) for regenerative doses of $0,10,20,30,40$, and $50 \mathrm{~Gy}$. A recycling point (open circle) is denoted as $10 \mathrm{~Gy}$. The recycling ratio is 1.06 . calibrated ${ }^{14} \mathrm{C}$ ages using IntCal09 (Reimer et al., 2009) were between 4,570 and 4,160 cal a BP ( 2 sigma). Conventional ${ }^{14} \mathrm{C}$ ages of shells collected from the artificial horizon of 4MSR were 4,310 \pm 40 a BP (Beta-280477). The calibrated ${ }^{14} \mathrm{C}$ ages using IntCal09 (Reimer et al., 2009) were $4,970-4,830$ cal a BP (2 sigma). The OSL ages, 7.9 $\pm 0.3 \mathrm{ka}$ of Farmana flood silt and 8.4-9.0 ka of 4MSR flood silt were stratigraphically consistent with the calibrated ${ }^{14} \mathrm{C}$ ages.

The period of enhanced moisture was 13-6 ka at the western extremity area of the Thar Desert (Chawla et al., 1992) and 12-8 ka at the southern margin (Juyal et al., 2003). Despite some regional variations of the Thar Desert, results clarify that moisture was present in any region of the Thar Desert during 9-8 ka. The obtained OSL ages show that sand dunes commenced piling up at 10-15 ka and that they had already existed at this location since $5 \mathrm{ka}$, and that aeolian deposition was subdued because of enhanced moisture during 9-8 ka. This can be interpreted as indicating that the scale of the Ghaggar River flood plain has remained roughly equal to that of the present day since at least $5 \mathrm{ka}$.

\section{CONCLUSION}

We measured OSL ages using the SAR protocol for sand of eight palaeo-dunes and two flood silts in Ghaggar Basin, in the north margins of the Thar Desert. The obtained OSL ages were, respectively, $15-10 \mathrm{ka}$ or $5 \mathrm{ka}$, and 9-8 ka. These OSL ages are fairly consistent with results obtained for other areas of the Thar Desert. Results show that the deposition of sand dunes had started and had already existed at 15-10 ka or $5 \mathrm{ka}$ in Ghaggar Basin. A period of dormancy of sand dunes for moisture occurred during 9-8 ka. 


\section{ACKNOWLEDGMENTS}

We wish to thank Drs. V. Shinde, M. Kumar, P. Shirvalkar and V. Dangi for their advice and help in fieldwork, and Drs. J. Yamamoto, K. Takemura and A. Uesugi, who provided many useful comments. This study was supported by the Environmental Change and the Indus Civilization (project 3-3) research project managed by the Research Institute for Humanity and Nature, Japan.

\section{REFERENCES}

Adamiec G and Aitken MJ, 1998. Dose-rate conversion factors: update. Ancient TL 16: 37-50.

Chawala S, Dhir RP and Singhvi AK, 1992. Thermoluminescence chronology of sand profiles in the Thar Desert and their implications. Quaternary Science Reviews 11(1-2): 25-32, DOI 10.1016/0277-3791(92)90038-A

Juyal N, Kar A, Rajaguru SN and Singhvi AK, 2003. Luminescence chronology of aeolian deposition during the late quaternary on the southern margin of Thar Desert, India. Quaternary International 104(1): 87-98, DOI 10.1016/S1040-6182(02)00137-4.

Kar A, 1993. Aeolian process and bedforms in the Thar Desert. Journal of Arid Environments 25(1): 83-96, DOI 10.1006/jare.1993.1044.

Murray AS and Wintle AG, 2000. Luminescence dating of quartz using an improved single-aliquot regenerative-dose protocol. Radiation Measurements 32(1): 57-73. DOI 10.1016/S1350-4487(99)00253$\mathrm{X}$.

Nagatomo T, Shitaoka Y and Kunikita D, 2007. IRSL Dating of the Sediments at the Neolithic Sites in the Russian Far East. Bulletin of Nara University of Education. 56(2): 1-66. (in Japanese with English abstract)

Nagatomo T, Shitaoka Y, Namioka H, Sagawa M and Wei Q, 2009.
OSL Dating of the Strata at Palaeolithic Sites in the Nihewan Basin, China. Acta Anthropologica Sinica 28(3): 276-284.

Palaeo-labo AMS dating group, 2011. In: Shinde V. Osada T and Kumar M (Ed.), AMS radiocarbon dating. Excavations at Farmana district, Rohtak, Haryana, India 2006-2008: 831-838.

Prescott JR and Hutton JT, 1994. Cosmic ray contributions to dose rates for luminescence and ESR dating: Large depths and long-term time variations. Radiation Measurements 23(2-3): 497-500, DOI 10.1016/1350-4487(94)90086-8.

Reimer PJ, Baillie MGL, Bard E, Bayliss A, Beck JW, Blackwell PG, Bronk Ramsey C, Buck CE, Burr GS, Edwards RL, Friedrich M, Grootes PM, Guilderson TP, Hajdas I, Heaton TJ, Hogg AG, Hughen KA, Kaiser KF, Kromer B, McCormac FG, Manning SW, Reimer RW, Richards DA, Southon JR, Talamo S, Turney CSM, Plicht J van der and Weyhenmeyer CE, 2009. IntCal09 and marine09 radiocarbon age calibration curves, 0-50,000 years cal BP. Radiocarbon 51: 1111-1150.

Saini HS and Mujtaba SAI, 2010. Luminescence dating of the sediments from a buried channel loop in Fatehabad area, Haryana: insight into Vedic Saraswati River and its environment. Geochronometria 37: 29-35, DOI 10.2478/v10003-010-0021-5.

Shinde V, Osada T and Kumar M, Ed., 2011. Excavations at Farmana District, Rohtak, Haryana, India 2006-2008.

Shitaoka Y, Nagatomo T and Obata N, 2009. Age determination of Ontake Pm1 pumice fall deposit (On-Pm1) by thermoluminescence method. The Quaternary Research 48: 295-300 (in Japanese).

Singhvi AK, Sharma YP and Agrawal DP, 1982. Thermoluminescence dating of sand dune in Rajasthan. Nature 295: 313-315, DOI $10.1038 / 295313 \mathrm{a} 0$.

Singhvi AK and Kar A, 2004. The aeolian sedimentation record of the Thar Desert. Proceedings of Indian Academy of Science (Earth and Planetary Science) 113: 371-401.

Wintle AG and Murray AS, 2006. A review of quartz optically stimulated luminescence characteristics and their relevance in singlealiquot regeneration dating protocols. Radiation Measurements 41(4): 369-391. DOI 10.1016/j.radmeas.2005.11.001. 